\title{
RODENTBORNE FUNGAL PATHOGENS IN WETLAND AGROECOSYSTEM
}

\author{
Manuel Thomas $^{{ }^{*}}$, Abraham Samuel K. ${ }^{2}$, Punnen Kurian ${ }^{3}$ \\ ${ }^{1}$ Tropical Institute of Ecological Sciences, Velloor P.O, K.K Road, Kottayam, 686 501, Kerala, India; ${ }^{2}$ Department of \\ Zoology, CMS College, Kottayam 686 001, Kerala, India; ${ }^{3}$ Department of Zoology, St., Mary's College, Maalam P.O, \\ Manarcadu 686032 Kerala, India.
}

Submitted: October 08, 2010; Returned to authors for corrections: January 10, 2011; Approved: August 30, 2011.

\begin{abstract}
The past few decades have witnessed an overwhelming increase in the incidence of fungal infections, particularly in immunocompromised individuals. Consequently, zoonotic diseases, especially through rodents constitute a prominent group among the emerging diseases. Rodents are commensal to man and related health risks are common. Water rats (Rattus norvegicus) are typical to Vembanadu-Kol wetland agroecosystems, where they can act as a good carrier nexus for pathogens. The present study evaluates the carrier status of water rats with respect to fungal pathogens. A total of fifty two fungi covering eighteen families were isolated. Among the isolates, eight were dermaptophytes and Chrysosporium sp. (89.18\%) was the frequent isolate. The source-wise analyses showed an increased isolation from ventral hair (67 isolates). Water rats of Vembanadu-Kol wetland agroecosystem are potent carrier of dermaptophytes and other opportunistic fungi, and strong carrier paths are existing too.
\end{abstract}

Key words: Rodents, Vembanadu-Kol wetland, Fungi, Agroecosystem

\section{INTRODUCTION}

Vembanadu-Kol wetland ecosystem situated on the south west coast of Indian peninsula $\left(09^{\circ} 50^{\prime} \mathrm{N} 076^{\circ} 45^{\prime} \mathrm{E}\right)$ is bestowed with the rich and unique biodiversity (1). However, pollution due to various causes are at an alarming scale (2). Recurring outbreaks of epidemic fevers such as dengue, leptospirosis and Japanese encephalitis are common among the interacting community. Fungal infections are so common in this area.

Fungal diseases are increasingly common mainly due to the expansion of immunocompromised populations at risk (3). Consequently, fungi once considered to be nonpathogenic became pathogenic and the expansion of geographic barrier by certain pathogens is observed in the past decades (4). Majority of the clinically relevant fungi are considered as zoonotic (5). Among the carrier animals, rodents have a pivotal role in carrying and spreading infectious agents.

Rodents are the most noxious vertebrate pests to man and his crops from time immemorial. Besides, they are the potential source of several infections to humans and animals

*Corresponding Author. Mailing address: Tropical Institute of Ecological Sciences, Velloor P.O, K.K Road, Kottayam, 686 501, Kerala, India.; E-mail: doctorfungus007@gmail.com 
(6). Rodentborne diseases are considered as a 'human health time bomb' (7). As rodents are commensal to man, the encounters are inevitable, especially in agro-ecosystems. Wetlands are unique ecosystems with typical flora and fauna, but rodents are common to such habitats too, especially commensal rat species. There has been a long historical association between wetlands and infectious diseases too (8).

Rodents in waterlogged environments include water rat (Rattus norvegicus), Black rat (Rattus rattus) and the larger bandicoot rat (Bandicota indica). Studies are lacking that establishes the link between rodent population and growing fungal infections. In this paper the carrier status of wetland rodents in relation to fungal pathogens is reported.

\section{MATERIALS AND METHODS}

Vembanadu-Kol Wetland is the largest lake in Asia (Ramsar site) and fringe area occupies the most extensive agricultural fields of the state. Water rats (Rattus norvegicus) were trapped from the wetland oil palm plantation of Kallara Grama Panchayath, Kottayam district, Kerala $\left(09.30^{\circ} \mathrm{N}\right.$ $\left.76.66^{\circ} \mathrm{E}\right)$. The Oil Palm farmers are regularly trapping rats in the area to prevent crop damage and four days such trapped rats in December 2007 were used for the study. The approval of Institute Animal Ethics Committee (IAEC) was obtained for the study. Rodents were trapped by using box type wooden live traps baited with Nymphae flowers which were set on the banks of canals in the oil palm plantation at 18.00 hours and checked at 06.00 hours in the next morning (Photo 1 \& 2 Study Area). Trapped rats were anesthetized using chloroform and weighed, morphometrically measured, sexed and taxonomically identified. 17 samples were collected from each specimen such as blood by cardiac puncture (1 sample), lungs (1 sample), ventral hair (4 samples), dorsal hair (4 samples), whisker (1 sample), Front nail (1 sample), hind nail (1 sample) and tail scrapings (4 samples). Hair, whisker, nail and tail scarpings were inoculated into Inhibitory Mould Agar (IMA) [HM 246; Lot No: WC050] and incubated at room temperature.
Blood and lung pieces were inoculated into Yeast Extract Phosphate Agar with ammonia (YEP) [HM 1421; Lot No: XB 134] and incubated at $37^{\circ} \mathrm{C}$ for dimorphic fungi. All the cultures were incubated for ten to fifteen days. Sufficiently grown colonies were subcultured onto Sabouraud Dextrose Agar, (SDA) [HM 063: Lot WC 030] incubated at room temperature. Colonies with retarded growth were subcultured on to a panel of media - Potato Dextrose Agar (PDA), PDA with blood (freshly drawn human blood), Malt Extract Agar, Oatmeal Agar (OMA) [HM 397: Lot WC 221] and Cornmeal Agar (CMA) [HM 146: Lot YJ 113]. The isolated fungi were identified based on the typical macroscopic and microscopic characteristics.

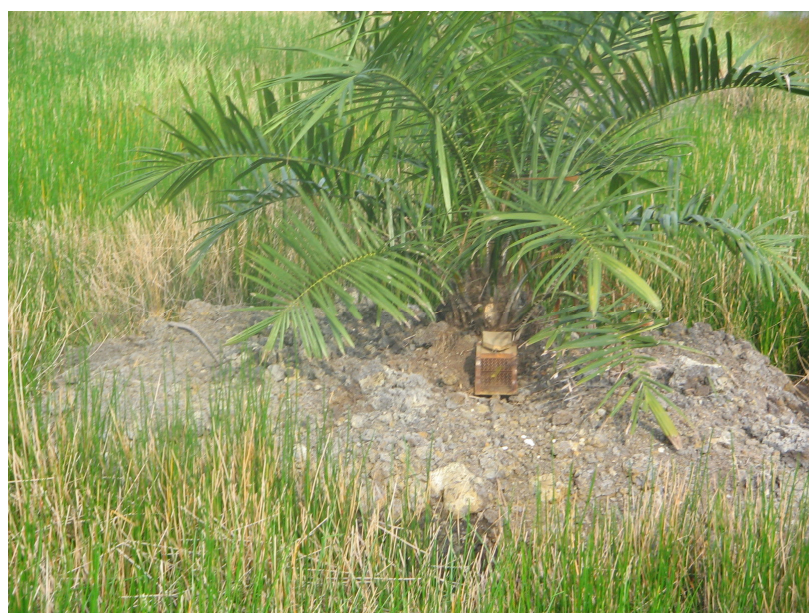

Photo 1: Live traps set in the field

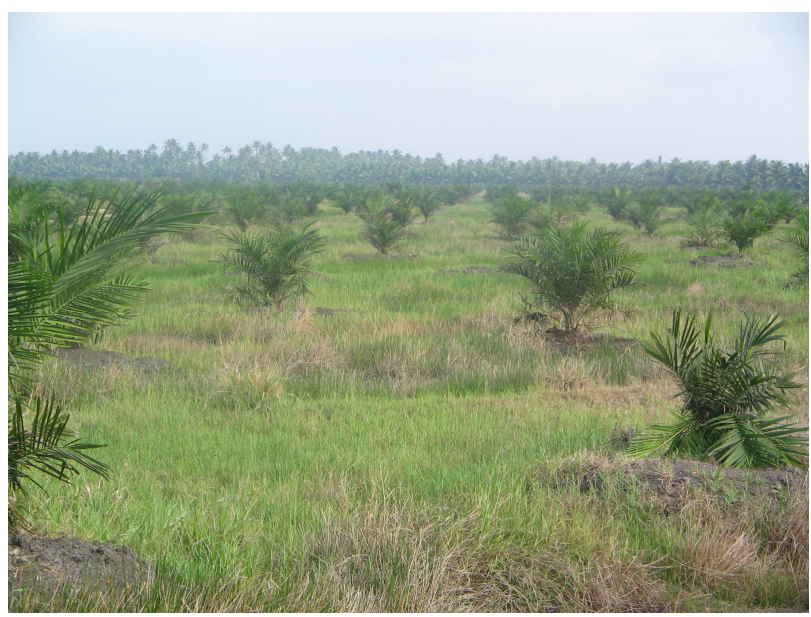

Photo 2: Study area 


\section{RESULTS}

Fifty two fungal species belonging to eighteen families including eight dermatophytes were isolated from the 629 (37 x 17) water rat samples (Table 1). The highest species diversity was observed with family Nectariaceae followed by Arthrodermataceae and Trichomonaceae. A preponderance of Chrysosporium sp. (89.18\%) followed by F. semitectum, A. flavus and C. geniculata $(32.43 \%)$ was observed. The most abundant genera among the isolates is Fusarium. Dermatophytes are represented by two genera - Trichophyton and Microsporum (4 species each). Among various tested body parts, ventral hair showed highest species diversity (67 isolates) followed by dorsal hair (51 isolates), tail scrapings (30 isolates), front nail (17 isolates) and least from the blood (only one isolate).

Table 1. List of fungal pathogens isolated $(n=37)$

\begin{tabular}{|c|c|}
\hline Fungi isolated & Frequency of occurrence (\%) \\
\hline \multicolumn{2}{|l|}{ I. Nectariaceae } \\
\hline 1. F. chlamydosporum & 18.91 \\
\hline 2. F. dimerum & 2.70 \\
\hline 3. F. moniliformis & 2.70 \\
\hline 4. F. oxysporum & 10.81 \\
\hline 5. F. proliferatum & 5.40 \\
\hline 6. F. semitectum & 32.43 \\
\hline 7. F. solani & 16.21 \\
\hline 8. F. sporotrichoides & 2.70 \\
\hline 9. Cylindrocarpon sp. & 2.70 \\
\hline \multicolumn{2}{|l|}{ II. Arthrodermataceae } \\
\hline 1. Microsporum audouinii & 16.21 \\
\hline 2. M. cookie & 24.32 \\
\hline 3. M. nanum & 5.40 \\
\hline 4. M. gallinae & 16.21 \\
\hline 5. Trichophyton mentagrophytes & 2.70 \\
\hline 6. T. schoelenii & 5.40 \\
\hline 7. T. violaceum & 2.70 \\
\hline 8. T.tonsurans & 5.40 \\
\hline \multicolumn{2}{|l|}{ III. Trichomonaceae } \\
\hline 1. Aspergillus flavus & 32.43 \\
\hline 2. A. fumigatus & 13.51 \\
\hline 3. A. nidulans & 2.70 \\
\hline 4. A. niger & 21.62 \\
\hline 5. A. restrictus & 2.70 \\
\hline 6. Paecilomyces variotii & 10.81 \\
\hline 7. Penicillium sp. & 2.70 \\
\hline 8. P. verrucosum & 16.21 \\
\hline \multicolumn{2}{|l|}{ IV. Pleosporaceae } \\
\hline 1. Bipolaris spicifera & 2.70 \\
\hline 2. Curvularia geniculata & 32.43 \\
\hline 3. C. lunata & 10.81 \\
\hline 4. Exherohilum & 2.70 \\
\hline 5. Dreschlera $\mathrm{sp}$. & 2.70 \\
\hline \multicolumn{2}{|l|}{ V. Hypocreaceae } \\
\hline 1. Gliocladium sp. & 8.10 \\
\hline 2. Trichoderma sp. & 2.70 \\
\hline 3. T. longibracheatum & 2.70 \\
\hline
\end{tabular}


VI. Chaetomiaceae

1. Chaetomium atrobrunneum 2.70

2. C. globosum 2.70

3. Humicola sp. 2.70

VII. Mucoraceae

1. Mucor ramosissimus 24.32

2. M. rouxianus $\quad 5.40$

3. Rhizopus arrhizus $\quad 2.70$

VIII. Microascaceae

1. Pseudoallescheria boydii $\quad 5.40$

IX. Dipodascaceae

2. Scopulariopsis brumptii $\quad 2.70$

X. Cunninghamellaceae

1. Geotrichum candidum 10.81

2. Blastoschizomyces capitatus $\quad 2.70$

XI. Onygenaceae

1. Cunninghamella bertolletiae $\quad 5.40$

XII. Myxotrichaceae

1. Chrysosporium sp. $\quad 89.18$

XII. Clavicipitaceae

1. Acremonium sp. $\quad 2.70$

XIV. Sacharomycetaceae

1. Candida albicans 2.70

XV. Sclerotiniaceae

1. Monilia sitophila $\quad 8.10$

XVI. Niessliaceae

1. Monocillium $\mathrm{sp}$. 2.70

XVII. Cephalothecaceae

1. Phialemonium obovatum 13.51

XVIII. Trichosporonaceae

\section{DISCUSSION}

Rodents represent an important mammalian group that has proven to be of increasing importance in the transmission of diverse diseases to humans, in recent decades. Investigations on fungal pathogens among rodents are significant, because rats and mice are commensal to man in agroecosystems and the transmission route of rodent-water-man is well established. The rise in fungal infections, especially with increasing immunocompromised cases is also alarming. The VembanaduKol wetland agroecosystems are heavily infested with a massive rodent population and human interactions are continuous and overexposive. The present investigation shows that Rattus norvegicus the principal rodent species of
Vembanadu-Kol wetland agroecosystem is potentially carrying a variety of fungal pathogens including dermatophytes. It is well established that the typical body structure of rodents support luxuriant growth of infectious agents especially fungi $(9,10)$.

Fusarium (8 species), Aspergillus sp. Microsporum sp. and Trichophyton sp. (4 each) were the predominant genera observed in the study. All are proved as pathogenic among man and rodent borne nature is also well reported. The genus Fusarium was involved in brain abscess (11), invasive fusariosis (12) and onychomycoses (13) in humans. A. flavus, A. niger and A. fumigatus are common allergens and causes severe opportunistic invasive infections in immunocompromised patients (14). Infections due to 
Aspergillus in humans can be varied like allergic alveolitis, allergic bronchopulmonary aspergillosis, aspergilloma, invasive aspergillosis and with mixed syndromes (15). Previous isolation reports of these fungi from rodents are also available (16). Thus, the presence of several potential fungal pathogens in a commensal animal in an agroecosystem is a matter of serious concern.

The most widely distributed fungi is Chrysosporium sp. $(89.18 \%)$ and it is considered as a common soil inhabitant, including Kerala too (17). Chrysosporium sp. is a keratinophilic fungi and have immense role in nature as keratin digesters (18). Among the dermaptophytes isolated M. cookie was more frequent than $M$. audouinii and $M$. gallinae. Dermatophytoses was considered as an emerging disease (19) and the relation between several dermatophyte species and small mammals like rodents are evident (20). The close contact between man-water-rat nexus in wetland agroecosystem paves an easy track for transmission of such infections. The different body parts showed variations in pathogenic diversity and density, and ventral hair showed highest fungal diversity followed by dorsal hair, tail scrapings and front nail. Those body parts are in more contact with soil and other surface materials showed relatively high rate of infection, which establishes the transmission routes. It should be noted that most of these isolates were previously reported from soil by hair baiting technique (21).

Rodents are the most common vertebrate commensal animal to man and they play as the most potential vertebrate carrier animal too (22). The ecology and transmission dynamics of these rodentborne infections are complex. The factors that influence transmission are unique to each disease and the fluctuations in rodent population or their habitat exerts profound influence in majority of rodentborne diseases (23). The typical ecology prevailing in Kerala (conglomeration of small holder ecosystem) favors easier transmission of fungal pathogens from rodents to humans, especially in agroecosystems.

\section{CONCLUSION}

The present investigation is a pioneer attempt in this part of the world and the fungal carrier status of rodents in wetland agroecosystems, is evident. The zoonotic risks associated with $R$. norvegicus in wetland agroecosystems can't be ignored in the wake of emerging zoonotic and fungal diseases.

\section{ACKNOWLEDGEMENTS}

The financial support from University Grants Commission (UGC), New Delhi was gratefully acknowledged. The authors are also grateful to Oil Palm Growers Association, Kallara and farmers for their generous support in rodent collection.

\section{REFERENCES}

1. Ascioglu, S.; Rex, J.H.; de Pauw, B.; Bennett, J.E.; Bille, J.; Crokaert, F.; Denning, D.W.; Donnelly, J.P.; Edwards, J.E.; Erjavec, Z.; Fiere, D.; Lortholary, O.; Maertens, J.; Meis, J.F.; Patterson, T.F.; Ritter, J.; Selleslag, D.; Shah, P.M.; Stevens, D.A.; Walsh, T.J. (2002). Defining opportunistic invasive fungal infections in immunocompromised patients with cancer and hematopoietic stem cell transplants: An international consensus. Clin. Infect. Dis., 34:7-14.

2. Begon, M. (2003). Disease: health effects on humans, population effects on rodents. In: Singleton GR, Hinds LA, Krebs CJ and Spratt DM (Eds.). Rats, mice and people: Rodent biology and management. Australian Centre for International Agricultural Research, Canberra. 13-19.

3. Davis, S.; Calvet, E.; Leirs, H. (2005). Fluctuating rodent populations and risk to humans from rodentborne zoonoses. Vector Borne Zoonotic Dis., 5(4): 305-314.

4. Desmukh, S.K. (2002). Incidence of keratinophilic fungi from selected soils of Kerala state (India). Mycopathologia, 156: 177-181.

5. El-Said, A.H.M. (1995). Keratinophilic fungi in soils of Yemen Arab Republic. Journal of Islamic Academy of Sciences, 8(4): 151-154.

6. Gugnani, H.C.; Wattal, B.L.; Sandhu, R.S. (1975). Dermatophytes and other kerationphilic fungi recovered from small mammals in India. Mykosen, 18: 529-538.

7. Hubalek, Z. (2000). Keratinophilic fungi associated with free-living mammals and birds. In:Kushwaha RKS and Guarro J (Eds.) Biology of dermatophytes and other keratrinophilic fungi. Revista lberoamericana de Micologia Apdo. Bilbao. 
8. Idemyor, V. (2003). Emerging opportunistic fungal infections: where are we heading? J. Natl. Med. Assoc., 95(12): 1211-1215.

9. Kataranovski, D.; Glamoclia, J.; Grbic, M.L.; Sokovic, M. (2007). First record of the presence of pathogenic and toxigenic fungi in Norway rat populations from urban and suburban habitats in Serbia. Arch. Biol. Sci.Belgrade, 59(3): $49-50$.

10. Kushwaha, R.K.S. (2000). The genus Chrysosporium its physiology and biotechnological potential. In: Kushwaha, R.K.S. and Guarro, J. (Eds.) Biology of dermatophytes and other keratinophilic fungi. Revista Iberoamericana de Micologia de Micologia, Bilbao. 1-12.

11. Mills, J.N.; Childs, J.E. (1998). Ecological studies of rodent reservoirs. Their relevance for human health. Emerg Infect Dis, 4(4): 529-537.

12. Mousavia, S.A.A.; Esfandiarpourb, S.; Salaria, C.; Shokri, H. (2009). Onychomycosis due to Fusarium spp. in patient with squamous cell carcinoma: A case report from Kerman, Iran. Journal of Medical Mycology, 19(2): 146-149.

13. Narayanan, P.S.; Thapanjith, T.; Thomas, A.P. (2005). A study on the icthyofauna of Aymanam Panchayath, in Vembanad wetland, Kerala. Zoo's Print Journal, 20(9): 1980-1982.

14. Nucci, M.; Marr, K.A. (2005). Emerging fungal diseases. Clin Infect Dis, 4: 521-526.

15. Nucci, M.; Marr, K.A.; Queiroz-Telles, F.; Martins, C.A.; Trabasso, P.;
Costa, S.; Voltarelli, J.C.; Colombo, A.L.; Imhof, A.; Pasquini, R.; Maiolino, A.; Souza, C.A.; Anaissie, E. (2004). Fusarium infection in hematopoietic stem cell transplant recipients. Clin Infect Dis, 38:12371242.

16. Panda, B.N. (2004) Fungal infections of lungs: the emerging scenario. Indian J Tuberc, 51:63-69.

17. Papini, R.; Nartoni, S.; Ricchi, R.; Mancianti, F. (2008). Dermatophytes and other keratinophilic fungi from coypys (Myocastor coypus) and brown rats (Rattus norvegicus). Eur. J. Wildl. Res, 54: 455 - 459.

18. Steinberg, G.K.; Britt, R.H.; Enzmann, D.R.; Finlay, J.L.; Arwin, A.M. (1983). Fusarium brain abscess. Journal of Neurosurgery Online, 58(4).

19. Stejskal, V.; Hubert, J.; Kubatova, A.; Vanova, M. (2005). Fungi associated with rodent feces in stored grain environment in the Czech Republic. Journal of Plant Diseases and Protection, 112(1): 98-102.

20. Taylor, L.H.; Latham, S.M.; Woolhouse, M.E.J. (2001). Risk factors for human disease emergence. Phil. Trans. R. Soc. Lond. B, 356: 983 - 989.

21. Upadhyay, V.P.; Ranjan, R.; Singh, J.S. (2002). Human-mangrove conflicts: The way out. Current Science, 83(11): 1328 - 1336.

22. Woodfolk, J.A. (2005). Allergy and dermatophytes. Clin. Micrbiol. Rev. 18(1): 30-43.

23. Zimmerman, R.H. (2001). Wetlands and infectious diseases. Cad. Saúde Pública, Rio de Janeiro, 17(Suplemento):127-131. 